\title{
Digital Romanticism in the Age of Neo-Luddism: the Romantic Circles Experiment
}

Steven Jones

Sjones1@luc.edu

Follow this and additional works at: https://ecommons.luc.edu/english_facpubs

Part of the Digital Humanities Commons, and the English Language and Literature Commons

\section{Recommended Citation}

Jones, S. "Digital Romanticism in the Age of Neo-Luddism: the Romantic Circles Experiment." Romanticism on the Net 41-42, 2006.

This Article is brought to you for free and open access by the Faculty Publications and Other Works by Department at Loyola eCommons. It has been accepted for inclusion in English: Faculty Publications and Other Works by an authorized administrator of Loyola eCommons. For more information, please contact ecommons@luc.edu.

\section{(c) (i) $\Theta$}

This work is licensed under a Creative Commons Attribution-Noncommercial-No Derivative Works 3.0 License. (c) Michael Eberle-Sinatra 1996-2006. 


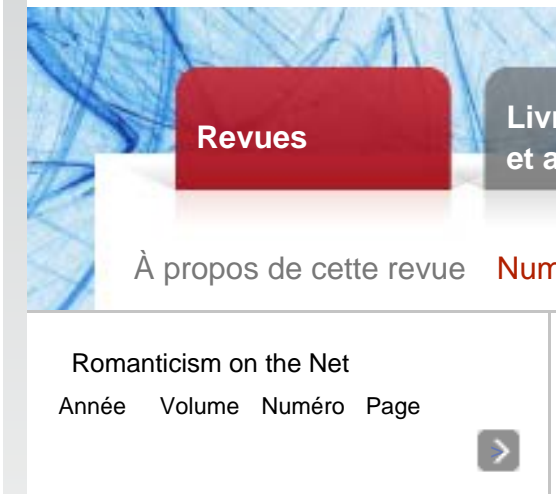

Sommaire du numéro

Texte intégral

Résumé

Bibliographie

Institution :

Usager en libre accès

\section{Romanticism on the Net}

Numéro 41-42, février-mai 2006

Romanticism on the Net 1996-2006: Celebrating Ten Years of Online Publishing

Sous la direction de Dino Franco Felluga

Direction : Michael Eberle-Sinatra (directeur)

Éditeur : Université de Montréal

ISSN : 1467-1255 (numérique)

DOI : 10.7202/013152ar

Documents

et données

Mots recherchés]

Recherche détaillée

\section{Article}

\section{Digital Romanticism in the Age of Neo-Luddism: the Romantic Circles Experiment}

Steven E. Jones

Loyola University Chicago

\section{Abstract}

The Romantic Circles Website, along with a number of other major projects in digital Romanticism, came online around 1995, a historical moment that also saw the emergence of neo-Luddism, in part as a reaction to the techno-hype of the Internet boom. At the time. neo-Luddites often claimed as a precedent the original historical Luddism of 1811-16, but they usually also Romanticized that collective labor subculture to fit their own latetwentieth-century ideas of "technology." This essay looks back at the interlinked assumptions in the air around 1995-neo-Luddite and Romantic-as the context out of which Romantic Circles defined its own engaged experiment in technology. Iw ill cite specific examples of digital technologies from our first year (two editions about technology, including the technology of texts), and one from our most recent year (an experiment in podcasting), in order to explain how we at Romantic Circles have attempted to work at the crossroads of Romanticism and technology, while stubbornly refusing to play the role of "natural Luddites,"

Another expression of a Luddistic kind, also contemporary with the Luddites, was Romanticism, beginning with Blake and Wordsworth and Byron particularly, who like 
the machine breakers were repulsed by the Satanic mills and getting-and-spending of the present and like them were mindful of the ruined paradise of the past.

-- Kirkpatrick Sale (1995)

Intellectuals and romantics like the poets Blake, Byron, Shelley and Wordsworth picked up that anti-technology theme, but identified with its other side. In the "dark Satanic mills" of industry, they saw the human spirit being stifled....

—- William Safire (1998)

1 The Romantic Circles Website, along with a number of other major projects in digital Romanticism, came online around 1995, at the same historical moment when neo-Luddism emerged as a cultural phenomenon. This essay looks back at the interlinked assumptions in the air around 1995-neo-Luddite and Romantic-as the context out of which Romantic Circles defined its own engaged experiment in technology. I will cite specific examples of digital technologies from our first year (two editions about technology, including the technology of texts), and one from our most recent year (an experiment in podcasting), in order to explain how we at Romantic Circles have attempted to work at the crossroads of Romanticism and technology, while stubbornly refusing to play the role of what C. P. Snow called "natural Luddites" (22).

By now the association of Romanticism with the Luddites and, in turn, with the Luddites' presumed anti-technology philosophy is widespread in popular culture. It also persists among some literary academics. My opening quotations above could have been multiplied indefinitely, but these two, from the most influential neo-Luddite writer of the 1990s and from a popular newspaper columnist, together exemplify the moment around 1995 when technology "futures" (in every sense of the word) were at a peak, and when, in reaction, a neo-Luddite "movement" briefly arose and was reported on by the media. [1] What often went unnoticed at the time was how much this conflict between technology and its discontents depended on established clichés about Romanticism. Their politics may be very different but Kirkpatrick Sale and William Safire share the fundamental literary-historical assumption that the Romantics were "natural Luddites." Romanticism, full of mindfulness, nostalgia and the transcendence of "the human spirit," is on one side of the assumed opposition; the Satanic Mills of industry, consumerism, and technology are on the other.

3 The popular notion that Romanticism was essentially an antitechnological philosophy found apparent support in some academic definitions current at the time, which, especially under the influence of Jerome McGann's The Romantic Ideology, stressed the posthumously constructed movement's ideological drive to transcend the material and political worlds. This transcendence, exemplified in the Wordsworth sonnet alluded to by Sale-in which this world which is the world of all of us is nonetheless too much with us-is easily enough construed as in keeping with an anti-technology worldview. This is more or less what happened in the press (and sometimes in the academy) around 1995: an antitechnological Romanticism and a Romantic version of Luddism were co-defined 
and sometimes simply conflated.

Sale's highly influential book argues for a historical precedent (though it often seems to argue for a homology) for 1990s antiglobalism. Its double subtitle-The Luddites and Their War on the Industrial Revolution: Lessons for the Computer Age-reveals a desire for a history that the activists could use. In public appearances Sale performed neo-Luddism, smashing a personal computer with his sledgehammer. He went on to construct a smooth continuity between the first and second industrial revolutions, drawing rhetorical strength from the textile workers in order to fuel a very different kind of movement, one that deliberately attempted to connect with the emergent anti-capitalist, antiglobalization groups on the ecological front. The ecology group Earth First! sold Ned Ludd Lives! T-Shirts, and some reportedly wore them to anti-World Trade Organization protests; "ecotage" and "monkeywrenching" (from Edward Abbey's 1975 cult novel, The Monkey-Wrench Gang) were provided with a ready-made tradition. And in September 1995, Ted Kaczynski's Unabomber manifesto (Industrial Society and Its Future) was published and republished on the Internet. Soon anarchist John Zerzan and other activists (including to some degree Sale himself) were publicly defending "Ted's" apocalyptic, libertarian, radically primitivist, often Romantic ideas-though of course not his bombs-and Earth First! found itself having to deny to reporters that it had any connection to Kaczynski.

Apart from these particular radical appropriations, however, Sale's kind of neoLuddism appealed mostly to white-collar workers, students, academics, and writers. The very different kinds of "machinery" being smashed in each case is a significant reminder of the gaps of two hundred years and two continents that were leapt over by the neo-Luddites-stocking frames versus plastic PCs, the tradesman's shop versus the "cube farm." This is not to deny all possibility of historical continuities. There are surely some significant connections between 1811 and 1995 (the context of laissez-faire capitalism, in early and late stages, among them), but Sale paints the connection in totalizing broad strokes, turning a complex labor subculture into a band of "rebels" in order to inspire 1990s activists as well as intellectual, "desk-chair" neo-Luddites, those in the position of being able to decide whether to voluntarily and selectively relinquish certain forms of mostly information technology. He often paints this picture by Romanticizing the Luddites, depicting them as ecologically minded, organic communitarians, nostalgic for a pre-capitalist way of life. Romanticism in turn is seen as Luddistic at its core, an ideology against technology.

6 In that climate-with Sale's brand of Romantic neo-Luddism reacting against the wildly inflated ideology fueling the tech-stock bubble-a number of major humanities computing projects came online in 1995. These were more than self-published home pages by academics, they were peer-reviewed, collaborative, scholarly projects. Alan Liu's groundbreaking list of lists-later converted to database form-the Voice of the Shuttle, had come online earlier, in 1994. He also collaborated with Laura Mandell, Rita Raley, Carl Stahmer, and Vince Willoughby to produce the Romantic Chronology in 1995-96. Simultaneously, in mid-1995, Neil Fraistat, Don Reiman, Carl Stahmer, and I began to work together to build Romantic Circles, a peer-reviewed Website devoted to publishing electronic editions of Romantic texts and Romanticist scholarship on the World Wide Web. The four of us collaborated from different 
locations for about a year, hand-coding HTML files and weaving them together under the technically sophisticated site designs of Stahmer, the only programmer among us, sharing them over dialup connections and discussing them on the telephone. The full site came online with an interface designed by Stahmer in 1996, and it soon began drawing upon the expertise of a wider collaborative team of section editors. That same year the present journal, Romanticism on the Net, edited by Michael Eberle-Sinatra, began to be published from an Oxford University server and (slightly later) a mirror site at Stanford University. 1996 also saw the online appearance of what would turn out to be one of the most important digital archives in the humanities, one which would later (2005) become the first electronic edition to win formal approval from the MLA's Committee for Scholarly Editions, The William Blake Archive, edited by Morris Eaves, Robert Essick, and Joseph Viscomi, with the support of the Institute for Advanced Technology in the Humanities under the direction of John Unsworth at the University of Virginia. Jerome McGann was also at IATH at the time working on The Rossetti Archive and beginning to publish research reports and essays about that experience in text encoding and image digitization. "The Rationale of Hypertext" first appeared online in 1995. (I still have an early "edition" of this essay, retrieved via the Gopher protocol and printed on a long piece of continuous-feed dot-matrix printer paper in 1995.)

The simplest explanation for all of this apparent synchronicity was of course available infrastructure. The Web itself was just old enough in 1995-96 to make online publication of such projects feasible (several had been in the works offline for years). Browser technology was far enough along and the user base in the humanities academic community was large enough for humanities Websites to make sense. In addition we were all probably responding (sometimes unwittingly) to institutional pressures to participate in the new knowledge-work economy both inside and outside the academy. More deliberately, we responded logically to changes in archiving by moving a certain amount of our own work online, in the process experimenting with new models of collaborative scholarship and publishing. These material causes granted, I also think the particular emergence of online Romanticism at that historical juncture had something to do with the public discourse at the time, which implicated Romanticism in the debate over the role of technology in culture. I know that my own interest in doing digital scholarship was motivated in part by the desire to engage in that debate from a more complex perspective regarding Romantic-period ideas of culture.

8 Our early experiment in Romanticism and technology was welcomed enthusiastically by some and was viewed with skepticism by others. More than once in the late 1990s I was asked by smirking colleagues what we Romanticists (sometimes they referred to us as "Romantics") were doing on the Internet-as if the irony might have escaped us. Of course the irony had not escaped us. The name of our Website gestured towards the interrelated social circles (of influence, reception, context) we saw as the structure of the literary and cultural exchanges of the Romantic period. But we were all students of Percy Shelley and one of us proposed at the time that "Romantic Circles" should also allude to the complex apocalyptic machinery or mills envisioned in Prometheus Unbound IV ("Ten thousand orbs involving and involved . . . I Upon a thousand sightless axles spinning"). Just right, we laughed among ourselves, 
for the apocalyptic and millennial tone then being applied to the global network, which had already, suddenly, come to serve as a synecdoche for technology as a whole. More seriously, we all believed then what Jay Clayton has recently argued, that "a critical engagement with technology, not withdrawal, is the best hope for what were once called humanist values" (213).

9 In fact the real question, it seemed to us, was not whether to be involved in technology, or whether Romantic literature was somehow inherently incompatible with technological media, but how precisely to respond to the increasingly Romantic rhetoric with which technology was itself being figured. As early as work by Leo Marx (and then by David Nye) it has been recognized that America in particular understands technology itself as a Romantic phenomenon, a sublime machine in the garden, what Wordsworth awkwardly posited as "the lawful offspring in Man's art" that Nature might embrace in some imagined "prophetic" future. More recently, Richard Coyne (2001) has outlined some of the Romantic, idealist, and utopian narratives that permeate constructions of digital culture. Technology marketing tells the same story: from the magic casements opening on fairy lands in those multiple-Windows logos, to the something evermore about to be that Moore's Law and each new technological development promises again and again, to that hacker's motto of individualism and imagination: "Think Different"-digital technology has tapped into often-unacknowledged Romantic assumptions for its popular appeal and rhetorical force. If Frankenstein has been constructed as a prophecy of the dark side of this technoromanticism, then Wordsworth's steamboats, viaducts and railways and Shelley's visionary "machinery" and utopian futurism often seemed in retrospect to anticipate the techno-hype, even as neo-Luddism, on the pessimistic side, was busy appropriating Romantic texts as its foundational authorities for an anti-technology philosophy.

10 Digital Romanticism circa 1995 confronted an entrenched set of contradictions and stood as a challenge to a series of assumptions and clichés, including two that contradicted one another: (1) on the one hand, the Romantic essence of "new technology," its visionary and transcendent possibilities; (2) on the other hand, the essentially antitechnological, "Luddite" ideology of Romanticism; but also (3) the inevitability of the "two cultures" in which literary scholars were "natural Luddites" and (4) the concomitant "naturalness" of the fit between certain forms of media and the ideology of Romanticism and Romanticist scholarship. This last assumption-that some media were more appropriate for Romantic studies than others-manifested itself as the anxious fetish of the book, which, after all, remained the major material object of our attention and scholarly affection. For a couple of years celebrations and jeremiads for the death of the book were unavoidable. One of the pleasures of working in the area of digital studies of Romanticism for the past decade has been the opportunity to fly in the face of all of these assumptions, just as a matter of course. From the platform of practical engagement with our specific projects, we've frequently been in a position to speculate on the meaningful connections and discontinuities between Romanticism and technology.

11 It is worth remembering that, if the Romantics were not Luddites, the Luddites were most certainly not Romantics. The historical Luddites were mostly textile workers in the counties of Nottinghamshire, Yorkshire, and Lancashire who, in the winter of 1811 and spring of 1812, began a series of loosely related 
campaigns of machine-breaking in response to the introduction of new kinds of machinery and labor practices that threatened their livelihoods, and also in response to high food prices and the infamous Orders in Council, trade restrictions that shrank the markets for their goods. They went out at night in armed bands, sometimes wearing masks, and broke the new kinds of wider stocking frames or new cloth-finishing machines, and sometimes other kinds of machinery, as well as committing arson and other acts of sabotage, and in a few cases they marched on large shops or mills in quasi-military actions. Some of them were shot or later hanged as a result. They invented a folk hero, their eponymous guerrilla leader, General Ned Ludd, under whose banner and in whose name they acted. As Kevin Binfield's recent collection of texts vividly illustrates, they also produced a good deal of discourse. They wrote threatening letters, proclamations, manifestoes, songs and ballads. They identified with and then claimed to overgo one local legendary outlaw, Robin Hood, and mythologized and preserved their own emerging labor subculture to the extent that their actions and texts worked together, with the help of the press, local officials, and Home Office spies, all of whom copied and transmitted Luddite texts and legends.

12 Many self-described neo-Luddites unwittingly participate in what E. P. Thompson (who was writing about the Luddites among other groups) famously called the "enormous condescension of posterity" (12), by confusing the Luddites with clichés associated with Romanticism, but also by giving the Luddites too little credit for making their own myths, creating their own labor subculture. They over-emphasize the Romantic idea of nature and the problem of individual consciousness and transcendence (and "ideas" and philosophical "problems" in general) when Luddism was all about anonymous, collective actions-though these included discursive actions, acts of writing. Such a view ignores the immanent engagement of the Luddites in the hotly contested moment of their own hard-fought history. It assumes Whiggishly that our own ecological concerns must have been the Luddites' concerns, at least in anticipatory outline, and that our own usually white-collar intellectual obsessions with authenticity and alienation and power were shared by, say, Yorkshire croppers in 1812.

13 More generally, neo-Luddites often begin with a very modern, highly abstract concept of "technology" itself. The Luddites and their contemporaries spoke of "machinery" and began to use the term to name a problem: in Victorian parlance, "the machinery question." But that was still a long way from the kind of inhuman and yet personified power often attributed today to "technology." Modern technology is commonly seen as an autonomous, "liquid," and malevolent force with a life of its own. Technology serves to give a local habitation and a name to a host of modern evils (which are often enough very real). Since the mid twentieth century, especially, we have increasingly spoken of technology as "wanting" something, as tending to "bite back" or "take over" or dominate us, of "threatening" to rule over us after the fashion of Victor Frankenstein's unfortunate creature. [2] In this spirit Mary Shelley's novel is repeatedly cited as a prophecy of this recent condition, as the first Luddite novel.

14 But the historical Luddites were themselves technologists of a sort, skilled 
artisans and machinists and masters of certain specialized techniques (including the use of huge, heavy hand shears, complicated looms, or large table-sized cropping or weaving machines) by which they made their living. That living and their right to their technology (in other words, their Trade) was what they fought to protect, not some Romantic idyll in an imagined pretechnological nature. The conflation of Romantic literature and Luddism often assumes that the poets are able to express what the workers could only do. And it frequently ignores the possibility that the Luddites engaged in symbolic and discursive actions-and that the poets may have aspired downward (as it were) to achieve the kind of immediate effects demonstrated in Luddite ballads and threatening letters. (See for example Byron's self-consciously radical songs on the Luddites.)

15 Part of the appeal of the Luddites for today's neo-Luddites is what is perceived as their closer connection to and control over material reality, their apparently clear-cut target: machines at which one could swing a hammer. In our own time technology is more elusive, more "liquid." Increasingly invisible yet everywhere at once, it is a metamachine pervading every aspect of life, leaving us no place of refuge. Nanotech and biotech and genetic engineering, genetically modified crops ("Frankenfood") and micro-organisms and micro-machines (the distinction is increasingly blurred) threaten to give technology dominion over our bodies, our very interiors. A side effect of this perceived increase in the autonomy and ubiquity of technology is a general anxiety and suspicion of anything technological, an anxiety that borders on a collective form of apophenia (the tendency to see patterns everywhere).

16 Undoubtedly this kind of general suspicion formed the background for many early reactions to the Internet among humanities intellectuals. Despite all the theory being published in cultural studies venues at the time on hypertext and cyberculture, a good number of those anti-technology reactions, arguably the dominant voices of neo-Luddism, were grounded not so much in postmodern theories of media, of simulation and simulacra, say, as in what we might term work-station anxieties-the sense that humanities academics and intellectuals were themselves being turned into what the high-tech business world was beginning to call "knowledge workers." To many that looked like the truly terrifying end-result of the wider rhetoric of technological determinism.

As Alan Liu has recently argued, this is a serious and legitimate fear based on fundamental changes in postindustrial business culture and the academy. As Liu shows, the new business culture has been fundamentally antihistoricist. "On the menu-bar of each of the business bestsellers, as it were, there is a big button marked 'Delete History"' (48). The management theory driving the technology industry in the 1990s, he argues, was "perhaps the most unmediated of antihistoricisms since the French Revolution (which presumed to throw out the relevant past to start over again in French Revolutionary Year One)..." (49). The postindustrial worldview holds that there is no real difference between the past and present that is not technical, so no real need for historical understanding per se. The exception, interestingly enough, is "when the contemporary raids the past for analogies to help it become even more efficient, a process that characteristically neutralizes the pastness of the past" (302). The telling example Liu cites is a book titled Elizabeth I CEO, but I would suggest that the same process is often at work in even politically committed neo- 
Luddism. Countless "presentist" articles appeared in the late 1990s with the basic theme of "Just like the Luddites ..." -as if the gaps of two hundred years and two continents meant next to nothing.

18 Liu rightly insists that humanities scholars must engage the knowledge-work culture of postindustrial capital if they are not to be redefined as easilyredundant, mere knowledge workers, that our mission in the new era must be to educate the incipient resistance to the ahistoricist hegemony of that culture, a resistance he associates with the stance of the "cool." As a specific corollary, I would argue, Romanticists have a responsibility to challenge facile attributions of the anti-technology philosophy of neo-Luddism to the historical Luddites, whose lived experiences and subcultural productions are after all part of the complex history of our period. On the literary side, specialists in Mary Shelley should never be satisfied with the vulgar truism that Frankenstein is the world's "first Luddite novel," for example, because, more than anyone, they have a deep historical understanding of the persistent and often positive significance of the examples of Benjamin Franklin, William Godwin, Joseph Priestly, Erasmus Darwin, and various progressive theories of natural history to that novel's author and her intellectual circle, not to mention crucial differences between her idea of science and our own idea of technology. Victor Frankenstein was made a "doctor," his laboratory was furnished with electrical oscillators and coils and switches, and those telling contact-point bolts were added to the neck of his creature by later stage and film adaptations, as the role of technology, in the modern sense, loomed ever larger and more monstrously within the increasingly mythical reception of Frankenstein.

19 The realm of networked technology, and the culture at large that has shaped it and is being shaped by it, badly needs the kind of history literary and cultural critics are positioned to provide. Snow's famous formulation notwithstanding, there is nothing "natural" in the "Luddism" of literary intellectuals. Such Luddism (in fact more properly called neo-Luddism) can only serve as a bar to historical understanding, especially of the crucial role played by science in culture, and to an effective engagement with our own historical moment. The roots of our idea of technology do indeed lie in our historical period of study, the era of the Romantics and the Luddites, but in ways much more complicated than either ahistoricist neo-Luddism or ahistoricist technoculture have seemed able or willing to explore. Engaging Internet culture (to choose a target more specific than the vaguely menacing, implicitly sublime "technology") has seemed to many of us the most productive way to begin those explorations. Another way to think about this imperative is found in Donna Haraway's extremely influential essay from the period just prior to Romantic Circles' start-up, "A Cyborg Manifesto." It argues that the position of effective intervention is from within the belly of the beast and that "taking responsibility for the social relations of science and technology means refusing an anti-science metaphysics, a demonology of technology, and so means embracing the skilful task of reconstructing the boundaries of daily life, in partial connection with others, in communication with all of our parts. . . . science and technology are possible means of great human satisfaction, as well as a matrix of complex dominations" (181). In a similar spirit Romantic Circles has set itself against a diminished, Romanticized version of the relation of literature and technology. Instead we have sought discipline-shaping engagements with specific technologies of 
textual markup and display, publication and access, and scholarly communication and performative/deformative interpretation, always with attention to the historical complexities of Romantic-period technology and culture.

20 In retrospect, it seems significant that the first two texts Romantic Circles brought online in 1996 were Mary Shelley's The Last Man and Percy Shelley's The Devil's Walk, a Romantic-period science-fiction novel and a radical broadside ballad of special interest to materialist textual critics. The combination, especially as published in a shared hypertextual environment, foregrounds "technology" in more than one sense-as a theme and as a medium, the techne of production, publication, dissemination, and reproduction of texts. Mary Shelley's novel, published in 1826, imagines a future plague that wipes out the human species. Her twenty-first century England contains very little in the way of technology in the modern sense, as one of the interconnected texts in our hypertext edition makes clear by contrast. "A Dialogue for the Year 2130 " by T. H. Lister is a silver-fork fantasy of futuristic fashionable society, published in the Keepsake for 1830. Its subtitle, "From the album of a modern sybil," suggests it may have been intended as a parody of Shelley's novel or other prophetic fictions of its kind. Simply hyperlinking this little sketch with Shelley's novel emphasizes how little of what we think of as technological trappings of science fiction the novel contains. By contrast the "Dialogue" depicts robotic hunting machines, mechanized steam-powered porters, automatic letter-writers, and iron yachts circumnavigating the globe. The contemporary availability of literary "machinery" of this sort calls attention to Shelley's authorial decisions in The Last Man, which is more a novel of socialscience-fiction, or of epidemiology perhaps, but more obviously represents the relatively undifferentiated, undisciplined continuum between science and sensibility. Building the edition as a complex cluster of hypertext lexias-weaving the text of the novel into a network of other short fiction by Shelley as well as texts such as Lister's-allows us to rethink the scientific and cultural landscape of the 1820s, to highlight for example the way in which casual international balloon flight in The Last Man is not "futuristic" at all, but rather looks back to the era of the Montgolfier brothers, the French Revolution, and Napoleonic displays of new technology, as much as it looks forward to Jules Verne. Technology in the modern disciplinary and specialized sense-as a "liquid" and disembodied force of machinery usurping the human-actually seems to have mattered very little to Mary Shelley as a theme, either in this novel or (less obviously, but just as demonstrably) in her first and more famous science-fiction novel. Neither book is a simple Luddite parable against technology.

21 One of the major characters in The Last Man was based on Byron, someone the Shelley circle naturally associated with the Luddite troubles centered in his home county. Claire Clairmont wrote to him from Bath-just after the summer of 1816, while we know that Mary Shelley was still composing Frankenstein-to give him the news from England:

Your Nottingham weavers (not of poetry dearest but of stockings) have risen. They fortified a village \& made out a long declaration. This Cobbett has printed cheap \& it is posted up \& down the country. It is really very well written \& uncommonly spirited. Two days ago 20,000 people met in the Spa fields near London Every body was alarmed.... 
This demonstrates (if there were any doubt) that the Luddites were among the contemporary topics of interest in the Shelley circle, especially where Byron was concerned. These are his weavers, according to Claire, an allusion to his Lordship's proprietary interest in Nottinghamshire and its inhabitants, of course, but also to his special political interest in the Luddites.

22 Back in March 1812 Lord Byron had made his first speech in the House of Lords, a rousing defense of the Luddites. Almost simultaneously with the speech, he published (anonymously) a satirical "Ode to the Framers of the Frame Bill." The Bill passed anyway, and on April 11, 1812 the most often recounted Luddite action took place (most prominently in Charlotte Brontë's Shirley), the attack on Rawfolds Mill in Yorkshire. Over a hundred closely drilled Luddites marched on the mill and were rebuffed by the owner and a handful of militia. Two Luddites were shot and mortally wounded on the spot. Byron's attempted intervention was in response to a crisis that gained national attention in 1812.

23 In that same year there were food strikes and other popular disturbances in Devonshire, and the young Percy Bysshe Shelley seems to have been drawn there because of the opportunity for radical intervention. Shelley printed and distributed a number of radical works in 1812, and as a result he spent some time in a print shop in Barnstaple. Some time in the summer of 1812 he may well have physically set the type himself for his anonymous broadside satire, "The Devil's Walk," as Fraistat and Reiman have speculated, or at least to have convinced someone else to do it. It's stimulating to imagine the possibility of the poet's actually placing the metal type in the printing press's forme, standing over the machinery-a different kind of "frame" from those the Luddites were smashing - that will eventually produce full-sized printed sheets containing his satirical and seditious stanzas. [3] It is not pure coincidence that this historical moment also saw the escalation of Luddite activities in Yorkshire, which unfolded in machine-wrecking as well as ballad-singing. The kingdom-wide climate of unrest lies behind both series of events.

24 The point is that Shelley was closely involved in the material form and production of the poem, and, when the broadsheet was printed, in its dissemination, partly by way of his agent and servant Dan Healy. Pasted up, handed out, distributed outside the usual channels of the booksellers or subscriptions, its radical intentions are written into the conditions of its own production and distribution. It may have been among the works, along with his Declaration of Rights, for example, that Shelley famously released tied to hot-air balloons or rolled up in bottles and cast into the Bristol Channel. Attempts at circumventing legal prosecution for sedition, certainly, these methods of distribution may also have been intended as a kind of agitprop, a provocative performance of radicalism and the spreading of enlightenment, even if for the poet's private pleasure or the benefit of his friends. At any rate, the meaning of "The Devil's Walk" cannot be separated from the technical processes of its dissemination, something that concerned Shelley from his earliest pamphlets and poems to his later imagery of winged seeds and incendiary sparks. His sonnet from the Esdaile Notebook, "To a balloon, laden with Knowledge," 
renders this concern as an explicit wish.

25 What stands out in the poem is the payload of enlightenment abstractions, the beautiful idealisms that the poet hopes will survive their journey, his "words among mankind." It is tempting to take the abstractions at their word. But the poem was embodied in a physical text tied to a kind of science experiment, a hot air balloon released to the winds. It is important to focus on the rhetorical pragmatics of Shelley's scheme of dissemination via the "ethereal way," his distribution system, as it were, rather than merely on the aspirational idealisms of the verse. That awareness produces a compelling image of Romantic poetry emerging through the algorithmic combination of what Jerome McGann has called the linguistic and bibliographic codes of textuality $(1991,13)-$ but also within the larger material nexus of "motions and means," the material conditions that made textual transmission a possibility.

26 The (facile) analogies arise unbidden. Yes, "The Devil's Walk" was partly selfpublished, set in type by "hacking" into existing systems of publication after hours, then distributed as risky "content" over an idealized "ether-net." And the whole "science-geek," outside-agitator role played by the poet in some ways amounts to a kind of samizdat-like action taken under the noses of home office spies, an anonymous re-mailing which caused Shelley's servant to spend his time in jail. These are mere analogies, deliberate anachronisms. The historical discontinuities between Shelley's wished-for "network" of enlightenment and our own idealized network of networks ca. 1995 are at least as significant as these apparent continuities, marking a great distance traveled, culturally, artistically, and politically-across two hundred years and two continents. But it helps to tell the story in this way, with a self-conscious attention to the continuities we inevitably tend to construct as well as the discontinuities and ruptures endemic to history, in part because it foregrounds the act of thinking historically about issues such as "networks" and "technology." In other words, digital editions make good historicist thought-experiments. Using technology to build a historically-aware digital text of "The Devil's Walk" allowed us to think dialectically about what Jay Clayton has recently called the "concealed circuit" running between Shelley's array of textual technologies and our own (7).

27 As we worked on the navigation and layout of the hypertext edition, exploiting the possibilities for representing in one place every version of the ballad (including one manuscript version copied out in a letter), and doing so at the microscopic level of text encoding, where the texts are tagged in order to be made readable by machines, processed digitally, we demonstrated in action the artisanal techne of textual studies in our own present moment, the digital era. In this case we worked with a set of texts that vividly illustrated the whole spectrum of text-history, encompassing problems ranging from composition (and compositing!) to publication and dissemination-not to mention a reception history limited by censorship, prosecution, and a conception of Shelley that had tended to devalue his topical and satirical works.

28 At the level of text encoding, this early HTML 3.0 text was a series of compromises between scholarly textual studies and the existing network. In the intervening decade Romantic Circles has grappled with the conflicts between the vernacular markup of the Web and the evolving community standards for archival and scholarly texts, the TEI (Text Encoding Initiative) in particular. In 
1995, after some discussion across a far-flung online community, we decided not to encode our texts in the structural markup system of SGML (the Standard Generalized Markup Language), despite its widespread reputation at the time as a business and scholarly standard and the evident limitations of the descriptive markup of HTML (Hypertext Markup Language), mostly because SGML text could not be successfully delivered and read over the Web. That decision still seems to us to have been the right one, since we have sent many subsequent scholarly texts (especially at the level of their linguistic or semantic content) out to the world via the vernacular publication network of the Web that would not have been useable in the meantime. Moreover, most earlier scholarly archives that were encoded in SGML up to the mid 1990s have now either been re-encoded or are in the process of being translated into XML, itself a kind of technological compromise between the goals of structural markup and the existing networks of dissemination and use. As I write this, Romantic Circles is exploring the possibility of converting a number of its existing texts to TEIcompliant XML and is working with others in the NINES group to produce a model for a broader, interoperative body of peer-reviewed scholarly digital texts and other resources, to be retrieved and aggregated, made available to users over the Web by way of RDF (Resource Description Framework) metadata tagging, a way of networking a diverse collection of widely distributed textual objects.

29 A related markup technology, RSS (now usually taken to mean "Really Simple Syndication") version 2.0 (with enclosures), lies behind a recent popular media trend, podcasting. Like Weblogs, out of which it grew, podcasting is precisely the kind of media development humanists too often reflexively dismiss as trendy. But the history of information technologies suggests how shortsighted such attempts at disciplinary purity can be. If we can see through the hype and marketing surrounding this development, we may find in podcasting a technology of media distribution well suited to our goals as scholars, humanists, and educators.

30 At least that is the assumption guiding Romantic Circles experiments in this direction. Under the editorship of Tilar Mazzeo, we recently began building an audio archive of contemporary poets reading their favorite Romantic poems, performances that are interpretations displayed in the form of sound. As Jerome McGann puts it, in a prefatory essay written specifically for Romantic Circles:

Recitation compels you to give a specific shape to the text's linguistic and prosodic relations. They can't speak the words until your mouth, your lungs, and-indeed-your whole body understands how to give them articulate shape so that someone else will also understand.

And to teach poetry as sound, and to study it as performance, we need audio files in circulation-even in profusion. The whole project works best when there are multiple readings of Keats's "Ode to a Nightingale," for example, by Robert Pinsky and Jennifer Grotz-and an indefinite, growing list of others-so that the accents and emphases, and embodied voices in general, can exemplify for those who have ears to hear the multiplicities and possibilities of the audible, recitable text. The dialectical possibilities opened up by poets of the twenty-first century reciting and interpreting Romantic texts are subtle and exciting. 
The full potential of such a site exists in its distributed use, its facilitation of a series of social feedback loops allowing for time-shifted downloads, creative applications, and direct commentary and exchange by users, both inside and outside the academy, and at the level of secondary as well as higher education. And all of that is a matter of technology. Besides the MP3 compression algorithm in which the audio files are encoded, and all the recording and mixing and editing technologies attendant upon creating the files in the first place, besides the HTML Web pages from which the files can be accessed, which are updated with a new reading every week, there is now an XML-based RSS syndication feed that turns an incrementally-growing collection of files from an archive into a podcast.

32 Podcasts are like audio Weblogs or brief radio shows distributed over the Internet for playing on computers or portable listening devices such as iPods. An RSS feed, a page-long set of specialized XML tags, makes it possible for software on the user's computer, either Apple's iTunes music player or some other "aggregator" (iPodder Lemon for example), to subscribe to the feed and receive automated updates of fresh files, daily or weekly, sent directly into their player. Those MP3 files can then be used in a variety of ways and at any time, repurposed to make up a specialized list of selected readings, say, or to play over a classroom audio-visual system or place on a school's network, or just to move to portable devices for individual mobile listening. There is nothing altogether new in the pieces that make up podcast technology. It is a pragmatically cobbled-together set of recording, markup, client-side and serverbased technologies that have over the past couple of years both helped to create and developed in response to a set of overlapping social networks of podcasters and podcast listeners, their RSS feeds and aggregators and players.

33 Podcasts range from repurposed public radio programs to individual talk and music shows sometimes reminiscent of "pirate radio" in the sixties and seventies. Subgroups exist within the subculture of podcasters, including for example an organized coalition of self-declared queer podcasters ("q-podders"). In some ways, of course, it is just the early Internet all over again, just as blogging is, but it is perhaps best to understand it as a newly overlaid grid, a remapping of the network for a specific purpose: to syndicate and distribute spoken-word and other media files under a user-controllable subscription model. The key is the use of the infrastructure of the Internet to carry timeshifted publication of "live"-recorded multimedia materials-all without centralized media producers-a subtle but significant difference from the broadcast model still governing attempts at "streaming" media over the Web in real time. This system encourages podcasters to focus on unforeseen uses and multiple platforms for playing among a diverse set of users, in fact to focus on the system of distribution itself as a non-transparent and non-trivial feature of the media exchange.

34 Pretty clearly this is a technology-or a bundle of technologies-that humanities textual scholars might do well to explore, if only we can get beyond our reflexive prejudices against vernacular audio-based media. In fact, the underlying technology of podcasting, based on a feed-and-aggregator, markup-andharvesting model, is conceptually closely related to the archival and scholarly experiments with texts underway in libraries and at organizations such as 
NINES using RDF. The Romantic Circles "Poets on Poets" site, with its theoretical focus on cumulative multiple performances and its obvious pedagogical applications, seemed to want to be a podcast, so a Ph.D. candidate at Loyola University, Doug Guerra, created the RSS feed, added the necessary tags to get us listed at Apple's popular iTunes Music Store (where we were recently listed among "New \& Notable" podcasts), and we began to conceive of the MP3 files as weekly podcasts as well as pieces in a growing scholarly archive. There is no reason we should not go on (as we are now planning to do) to develop a larger and more general section at the Website called Romantic Circles Audio, where MP3 podcasts of brief lectures, conference talks, interviews, audio tours of significant locales, and recitations of poetry by prominent scholars, students, and others, can be mounted with their own feeds, alongside the growing archive of MP3s by contemporary poets.

35 C. P. Snow was wrong. Literary intellectuals and humanities scholars are not natural Luddites. And there is nothing essentially resistant to technological processing and distribution even in, say, Clare's or Wordsworth's poetry. This is now clearer than ever, when we can subscribe to a particular series of interpretive recitations of this poetry in the form of podcasts and listen through earbuds on the subway or through loudspeakers in front of a classroom. But that does not mean that there is nothing Romantic-in all that term's historically inflected and complicated meanings-about our urge to leverage networked information technology for the educational and scholarly ends of the humanities. We are well aware that we sometimes find ourselves in the awkward position of Percy Shelley in 1812, that year when the Luddites were marching up in Yorkshire, as he set loose his hopeful balloons in the prevailing winds. Like the idealist poet, we may well (sooner or later) be accused of reaching no one, or no one who counts, with our packets of poetry. Still, the hopeful desire to communicate, to use networks of communication collaboratively to make and remake knowledge, remains for us a point of ambivalent continuity with the Romantic poets, though it's a continuity about which we try to be self-conscious and self-critical. But, then again, we are not so convinced that everything about Shelley's balloons can be explained away as idealist, as seeking transcendence (through the vehicle of hot air). We also have occasion to remember another, just as vivid, image of the poet (though we know it is largely imagined): hands smudged with ink, setting bits of metal type in metal and wooden frames in order to make a text, using for his own purposes the machinery at handmachinery of material distribution, rhetorical pragmatics, the limited and yet concentrically rippling technologies of everyday intellectual exchange.

\section{Notes}

[1] The article often cited by later neo-Luddites as an origin-text is Chellis Glendenning's 1990 "Towards a Neo-Luddite Manifesto." For a historical look at the reception of the idea of Luddism, see my Against Technology: from the Luddites to Neo-Luddism.

[2] This commonplace assumption is explored in Langdon Winner's Why Things 
Bite Back, for example.

[3] For a thoughtful treatment of Byron's Luddite texts in relation to the technology of publishing, see Tom Mole.

\section{Works Cited}

Binfield, Kevin, ed. Writings of The Luddites. Baltimore: Johns Hopkins University Press, 2004.

Clairmont, Claire. The Clairmont Correspondence:Letters of Claire Clairmont, Charles Clairmont, and Fanny Imlay Goodwin, 1808-1879, ed. Marion Kingston Stocking, 2 vols. Baltimore and London: Johns Hopkins University Press, 1995. I: 89-95 (October 27-19 November 1816).

Clayton, Jay. Charles Dickens in Cyberspace: The Afterlife of the Nineteenth Century in Postmodern Culture. Oxford: Oxford University Press, 2003.

Coyne, Richard. Technoromanticism; Digital Narrative, Holism, and the Romance of the Real. Cambridge, MA: MIT Press, 1999.

Glendenning, Chellis. "Towards a Neo-Luddite Manifesto." Utne Reader 38 (March-April 1990): 50-53.

Haraway, Donna J. "A Cyborg Manifesto: Science, Technology, and SocialistFeminism in the Late Twentieth Century." In Simians, Cyborgs, and Women: The Reinvention of Naure. New York: Routledge, 1991, 149-81.

Jones, Steven E. Against Technology: From the Luddites to Neo-Luddism. New York and London: Routledge, 2006.

Liu, Alan. The Laws of Cool; Knowledge Work and the Culture of Information. Chicago and London: University of Chicago Press, 2004.

McGann, Jerome. "The Rationale of HyperText." <http://www.iath.virginia.edu/public/jim2f/rationale.html>.

McGann, Jerome. "The Romantic Ideology: A Critical Investigation. Chicago and London: University of Chicago Press, 1983.

McGann, Jerome. The Textual Condition. Princeton: Princeton University Press, 1991.

Marx, Leo. The Machine in the Garden: Technology and the Pastoral Ideal in America. 1964; Oxford: Oxford University Press, 2000.

Mole, Tom. "Byron's 'Ode to the Framers of the Frame Bill': The Embarrassment of Industrial Culture." Keats-Shelley Journal 52 (2003): 111129.

NINES (Networked Infrastructure for Nineteenth-Century Electronic Scholarship). <http://www.nines.org>.

Nye, David. American Technological Sublime. Cambridge, MA.: MIT Press, 1996.

Romantic Chronology. <http://english.ucsb.edu:591/rchrono/>. 
Romantic Circles. <http://www.rc.umd.edu/>.

The Rossetti Archive. <http://www.rossettiarchive.org/>.

Safire, William. "Return of the Luddites." New York Times Magazine (December $6,1998)$.

Sale, Kirkpatrick. Rebels Against the Future: The Luddites and Their War on the Industrial Revolution: Lessons for the Computer Age. Reading, MA.: AddisonWesley, 1995.

Snow, C. P. The Two Cultures:and A Second Look.1959; Cambridge: Cambridge University Press, 1979.

Thompson, E. P. The Making of the English Working Class. New York: Random House, 1963. Vintage edn., 1966.

Voice of the Shuttle. <http://vos.ucsb.edu/>.

The William Blake Archive. <http://www. blakearchive.org/>.

Winner, Langdon. Autonomous Technology: Technics-out-of-Control as a Theme in Political Thought. Cambridge, MA. and London: MIT Press, 1977.

Auteur: Steven E. Jones

Titre : Digital Romanticism in the Age of Neo-Luddism: the Romantic Circles Experiment

Revue : $\quad$ Romanticism on the Net, Numéro 41-42, février-mai 2006

URI : $\quad$ http://id.erudit.org/iderudit/013152ar

DOI : $\quad 10.7202 / 013152 a r$

Copyright (c) Michael Eberle-Sinatra 1996-2006 - All rights reserved 